\title{
An Investigation of Conflict Resolution Strategies for the Students of Elementary School Teacher Education Study in Online Learning during the COVID-19 Pandemic
}

\author{
Galih Dani Septiyan Rahayu ${ }^{\otimes_{1}}$, Bunyamin Maftuh2 \& Elly Malihah ${ }^{3}$ \\ I Elementary Teacher Education Study Program, IKIP Siliwangi, Cimahi, Indonesia \\ 2 Pendidikan IPS, Universitas Pendidikan Indonesia, Bandung, Indonesia \\ ${ }_{3}$ Pendidikan Sosiologi, Universitas Pendidikan Indonesia, Bandung, Indonesia \\ \galih040990@ikipsiliwangi.ac.id
}

\begin{abstract}
This study aims at identifying various types of conflicts experienced by students of elementary school teacher study program during online learning of elementary social studies learning courses during the COVID-19 pandemic, and determining the strategies they used to resolve conflicts they encountered. This study uses a descriptive research method with a survey design. The research participants were 4th semester students of the PGSD study program in a private university in the West Java region, totaling 243 that consisted of 182 female students and 61 male students. The instruments used in this study were interviews that were used to identify the conflicts experienced by students during online learning, and closed questionnaires that were distributed to determine the strategies used to resolve the conflicts; which were analyzed descriptively. Based on the data obtained from the interviews, it was revealed that the conflicts experienced by students during online learning were completing group assignments, bullying between students, discriminatory attitude, and acknowledging/taking goods/works of others without asking permission. Meanwhile, based on the data obtained from the questionnaires regarding the students' strategies in resolving conflicts, it was found that students used cooperative strategies in resolving these conflicts.
\end{abstract}

Keywords: conflict, resolving conflicts, online learning, COVID-19 pandemic

How to Cite: Rahayu, G., Maftuh, B., \& Malihah, E. (2021). An Investigation of Conflict Resolution Strategies for the Students of Elementary School Teacher Education Study in Online Learning during the COVID-19 Pandemic. Mimbar Sekolah Dasar, 8(3), 281-294. doi:https://doi.org/10.53400/mimbar-sd.v8i3.35483 .

INTRODUCTION The learning process in the even semester of 2020/2021 in all universities throughout Indonesia was held based on the Joint Decree of the Minister of Education and Culture, Minister of Religion, Minister of Health, and Minister of Home Affairs, Number 04/KB/2020, Number 737 of 2020, Number HK.01.08/Menkes/7093/2020, and Number 420-3987 of 2020 concerning Guidelines for the Implementation of Learning for the 2020/2021 Academic Year and 2020/2021 Academic Year during the Coronavirus Disease 2019 (COVID-19) Pandemic, and Circular Number 6 in 2020 regarding the implementation of learning in the even semester of 2020/2021 Academic Year. This was a new situation that held the potential to have negative impacts on students. Therefore, it was necessary to conduct a survey regarding their experiences during online learning (Rahayu et al., 2020; Rahayu \& Fauzi, 2020).

This survey was important because when viewed from the perspective age, the students were between 18-21 years old, which were categorized as late adolescents (Ayas et al., 2010). 
Galih Dani Septiyan Rahayu, Bunyamin Maftuh \& Elly Malihah, An Investigation of Conflict Resolution...

Adolescents facing a changing environment and new conditions may experience some difficulties and challenges. The accumulation of emotions in the face of some difficulties and challenges can lead to conflict (Akan, 2020). Therefore, the survey in this study focused on the students' experiences during online learning, particularly the conflicts they experienced and how to resolve them.

Conflict is something that is natural and must be experienced by every individual, it has a positive impact as well as a negative impact (Tuimur \& Chemwei, 2015). For a conflict to have a positive impact, individuals need to have conflict resolution skills such as knowing the source of the conflict, who is in conflict, and the right strategies and tactics to resolve the conflict (Gibbons, 2010).

This study is based on the results of previous studies on conflict resolution. Shanka \& Thuo (2017) concluded that the school leaders need to understand the sources of conflicts and have the mechanisms of opportunity for staff to voice their concerns. Additionally, the leaders need to continuously build leadership competencies; be open to change, and involve and provide the staff with opportunities to grow. Furthermore, the schools' leaders should look for ways to acquire and expand funding sources. A study by Tuimur \& Chemwei (2015) suggested that the current preparation of teachers to teach conflict and conflict resolution is inadequate with regards to their ability to design relevant teaching and learning resources and effectively use them in the teaching and learning process. In addition, the available instructional materials in the sampled schools were insufficient. Lastly, a study by Ayas et al (2010) revealed that adolescents generally tend to use destructive and non-cooperative conflict resolution strategies, such as physical violence, cursing, joking, nicknaming, jealousy in interpersonal conflicts. Also, the results indicated that the use of conflict resolution strategies was found to significantly differ with regard to gender.

Following an analysis of these studies, it was concluded that there has not been any study on conflict resolution involving elementary teacher education (PGSD) students in online learning during the COVID-19 pandemic. Therefore, the proposed research questions are: (1) what are the conflicts experienced by PGSD students during online learning? and (2) what are the strategies used by them in resolving these conflicts? The novelty of this study includes an investigation that was carried out to analyze the strategies of PGSD students in overcoming conflicts in online learning during the COVID-19 pandemic. This is a novelty because, based on the results of several previous studies, there has not been any study that investigated students' strategies in overcoming conflicts in online learning during the COVID-19 pandemic. In addition, the contribution of this study is to determine what kind of learning is appropriate to be implemented during online learning, and to match students' strategies in resolving conflicts. 


\section{THEORETICAL FRAMEWORK}

\section{Conflict Resolution}

Conflict is something natural that is experienced by every individual in everyday life and it can have a positive impact as well as a negative impact on individuals involved in the conflict or on those not involved in it (Kreidler, 1997; Mishra, 2021). For a conflict to have positive impacts, individuals need to have resolution skills such as knowing the sources of the conflict, who are involved in it, and the right strategies and tactics to resolve it (Crawford \& Bodine, 1996; Gibbons, 2010). The positive impacts that individuals can have when they are able to resolve conflicts is that they have good personalities such as having good problem-solving skills, good communication skills, good critical thinking, and creative thinking skills (Yavuzer, 2012).

The types of conflicts based on their scope are as follows: (1) Intrapersonal conflict, which is a conflict occurring within individuals. Differences in goals, interests, ethical questions, and other problems can lead to this type of conflict; (2) Interpersonal conflict is a conflict that is caused by problems or concerns between individuals: (3) Intra-group conflict, the one that occurs between people, members, or factions belonging to the same group; (4) Intergroup conflict, a type of conflict arising between different groups of society; for example, between different classes, different organizations, different groups and so on; (5) National conflict, which is a conflict that arises within a nation, where various groups from the same nation are involved; (6) International conflict, which is a conflict arising between different countries/nations for various reasons (Bakken \& Buhaug, 2021; labal et al., 2017). In this study, the conflict being investigated focuses on interpersonal conflict in online learning during the COVID-19 pandemic.

According to Kreidler (1997), there are five dimensions of conflict, namely (1) sources of conflict i.e. Is it over? Resources? Values and beliefs? Emotional goals and needs? (2) Relationship between conflicting parties i.e., is the party-friendly or hostile? How interdependent are the parties? Is there a balanced strength? Is one side stronger than the other? How well do they know each other? (3) the history of the conflict i.e. How long (duration)? How often (frequency)? What is the emotional or violent intensity of the conflict? How familiar, interesting, and visible to the people involved? (4) the opposing parties or groups i.e. Who/how many are involved? Is the conflict internal, interpersonal, intergroup, intragroup, international, or global? and (5) responses to conflict i.e., how do people and groups choose to deal with the conflict? violently or nonviolently? By avoiding, spreading, or engaging in conflict? By coercing, accommodating, or solving problems collaboratively?

After understanding the meanings, types, and dimensions of the conflict in order to realize conflict resolution, it is necessary to know conflict management. The management or conflict resolution strategy according to Doe \& Chinda (2015), Kreidler (1997), and Shanka \& Thuo, 
Galih Dani Septiyan Rahayu, Bunyamin Maftuh \& Elly Malihah, An Investigation of Conflict Resolution...

(2017) is avoiding conflict, accommodating conflict, compromising on conflict, directing and controlling conflict, and working together in resolving conflict.

\section{METHOD}

\section{Research Design}

The method used in this study is descriptive research with a survey design. It is in accordance with the objectives and questions of this study because it can obtain measurable and easy-toanalyze data (Guo \& Yang, 2012). The procedure of this study consists of three stages, namely planning, implementation, and evaluation. The planning stage consists of analyzing conflict resolution activities, compiling research instruments, and validating instruments. The implementation stage consists of interviewing students and distributing questionnaires, whereas the evaluation stage consists of processing and analyzing data obtained from interviews and questionnaires, as well as drawing conclusions.

\section{Participant}

This study was conducted in one of the private universities in West Java Province, with the subjects of the study involving $4^{\text {th }}$-semester students of PGSD study program, totaling 243 consisting of 182 female students and 61 male students. The selection of the participants of this study was because the university was one of the universities carrying out full online learning so that it was in line with the purpose of this research, which was to identify the conflicts experienced by students during online learning and the strategies and tactics they used to resolve these conflicts.

\section{Data Collection}

There are two instruments used in this study. Interviews were conducted to identify the conflicts experienced by students during online learning, and questionnaires were distributed to identify the strategies and tactics used to resolve the conflicts. These instruments were considered appropriate to obtain information about the conflicts experienced and how the strategies and tactics are carried out by the students to resolve these conflicts. The use of interviews and questionnaires is considered appropriate in studies with a survey design (Gall et al., 2014). These instruments are distributed online using google forms application. The interview and questionnaires used in this study are as follows:

Table 1. Interview guidelines regarding conflicts experienced by elementary teacher education study program (PGSD) students during online learning

\section{Interview questions}

Answer

1. Do you have problems or conflicts with your friends during online learning?

2. If you experience problems or conflicts, please state what problems or conflicts you experienced during online learning. 
Table 2. Questionnaire on students' strategies and tactics in resolving conflicts during online learning

\begin{tabular}{|c|c|c|}
\hline Questionnaire & Strategies & Tactics \\
\hline \multirow{7}{*}{$\begin{array}{l}\text { Students' } \quad \text { strategies } \\
\text { and tactics in resolving } \\
\text { conflicts encountered } \\
\text { when working on group } \\
\text { assignments }\end{array}$} & Avoidance & I prefer being silent \\
\hline & Strategy (Score 1) & $\begin{array}{l}\text { I go away from there } \\
\text { I forget over time }\end{array}$ \\
\hline & Destructive & I threaten him/her \\
\hline & Strategy (Score 2) & $\begin{array}{l}\text { I report him/her to the lecturer } \\
\text { I stop being friends with him/her }\end{array}$ \\
\hline & $\begin{array}{l}\text { Conditional } \\
\text { Strategy (Score 3) }\end{array}$ & $\begin{array}{l}\text { I try to solve it by talking first. If I can't get the } \\
\text { result, I threaten him/her }\end{array}$ \\
\hline & & $\begin{array}{l}\text { First, I warn him/her. If he/she does it again, I } \\
\text { report him/her to the lecturer }\end{array}$ \\
\hline & $\begin{array}{l}\text { Cooperative } \\
\text { strategy (Score 4) }\end{array}$ & $\begin{array}{l}\text { I ask him/her why s/he didn't do the group } \\
\text { work, then invite him/her to work in groups } \\
\text { I tell him/her that what he/she does is wrong } \\
\text { then invite him/her to work in groups }\end{array}$ \\
\hline \multirow{7}{*}{$\begin{array}{l}\text { Students' } r \text { conflict } \\
\text { resolution strategies } \\
\text { and tactics in solving } \\
\text { bullying problems }\end{array}$} & Avoidance & I prefer being silent \\
\hline & Strategy (Score 1) & $\begin{array}{l}\text { I go away from there } \\
\text { I forget over time }\end{array}$ \\
\hline & Destructive & I threaten him/her \\
\hline & Strategy (Score 2) & $\begin{array}{l}\text { I do the same to him/her } \\
\text { I stop being friends with him/her }\end{array}$ \\
\hline & $\begin{array}{l}\text { Conditional } \\
\text { Strategy (Score 3) }\end{array}$ & $\begin{array}{l}\text { First, I try to solve it by talking. If I can't get the } \\
\text { result, I threaten him/her }\end{array}$ \\
\hline & & $\begin{array}{l}\text { First, I warn him/her. If he/she does it again, I } \\
\text { do the same to him/her }\end{array}$ \\
\hline & $\begin{array}{l}\text { Cooperative } \\
\text { strategy (Score 4) }\end{array}$ & $\begin{array}{l}\text { I ask him/her why he/she bullies me, then tell } \\
\text { him/her to apologize } \\
\text { I tell him/her that what s/he does is wrong, } \\
\text { then tell him/her to apologize }\end{array}$ \\
\hline \multirow{8}{*}{$\begin{array}{lr}\text { Student } & \text { conflict } \\
\text { resolution } & \text { strategies } \\
\text { and tactics in resolving } \\
\text { discriminatory problems }\end{array}$} & Avoidance & I prefer being silent \\
\hline & Strategy (Score 1) & $\begin{array}{l}\text { I go away from there } \\
\text { I forget over time }\end{array}$ \\
\hline & Destructive & I threaten him/her \\
\hline & Strategy (Score 2) & $\begin{array}{l}\text { I do the same to him/her } \\
\text { I stop being friends with him/her }\end{array}$ \\
\hline & $\begin{array}{l}\text { Conditional } \\
\text { Strategy (Score 3) }\end{array}$ & $\begin{array}{l}\text { First, I try to solve it by talking. If I can't get the } \\
\text { result, I report him/her to the lecturer }\end{array}$ \\
\hline & & $\begin{array}{l}\text { First, I warn him/her. If he/she does it again, I } \\
\text { stop being friends with him/he }\end{array}$ \\
\hline & & I ask him why he/she is discriminatory, then tell \\
\hline & $\begin{array}{l}\text { cooperative } \\
\text { strategy (Score 4) }\end{array}$ & $\begin{array}{l}\text { I tell him/her that what he/she does is wrong, } \\
\text { then tell him/her to apologize }\end{array}$ \\
\hline \multirow{2}{*}{$\begin{array}{lr}\text { Students' } & \text { conflict } \\
\text { resolution } & \text { strategies } \\
\text { and tactics in resolving }\end{array}$} & Avoidance & I prefer being silent \\
\hline & Strategy (Score 1) & I go away from there \\
\hline
\end{tabular}


Galih Dani Septiyan Rahayu, Bunyamin Maftuh \& Elly Malihah, An Investigation of Conflict Resolution...

\begin{tabular}{|c|c|c|}
\hline Questionnaire & Strategies & Tactics \\
\hline \multicolumn{3}{|l|}{ the problem of taking a } \\
\hline \multirow{8}{*}{$\begin{array}{l}\text { things } \\
\text { permission }\end{array}$} & Destructive & I threaten him/her \\
\hline & Strategy (Score 2) & I do the same to him/her \\
\hline & & I stop being friends with him/her \\
\hline & $\begin{array}{l}\text { Conditional } \\
\text { Strategy (Score 3) }\end{array}$ & $\begin{array}{l}\text { First, I try to solve it by talking. If I can't get the } \\
\text { result, I report him/her to the lecturer }\end{array}$ \\
\hline & & $\begin{array}{l}\text { First, I warn him/her. If he/she does it again, I } \\
\text { stopped being friends with him/her }\end{array}$ \\
\hline & & I asked him/her why he/she takes something \\
\hline & Cooperative & $\begin{array}{l}\text { Without permission, then tell him/her to } \\
\text { apologize }\end{array}$ \\
\hline & strategy (Score 4) & $\begin{array}{l}\text { I tell him/her that what he/she does is wrong, } \\
\text { then tell him/her to apologize }\end{array}$ \\
\hline
\end{tabular}

\section{RESULTS}

Following processing and analysis of data obtained from interviews, it was revealed that the conflicts experienced by the $4^{\text {th }}$ semester PGSD students in online learning during COVID-19 Pandemic were conflicts in completing group assignments, bullying, discriminatory attitudes, and taking things/works of others without permission.

Following processing and analysis of data obtained from questionnaires, resolution strategies implemented by PGSD students to resolve conflicts with other students during online learning are as follows:

Table 3. PGSD students' conflict resolution strategies and tactics in resolving conflicts in the process of working on their assignments

\begin{tabular}{|c|c|c|c|c|c|}
\hline \multirow[b]{2}{*}{ Strategies } & \multirow[b]{2}{*}{ Tactics } & \multicolumn{2}{|c|}{$\begin{array}{c}\text { Female } \\
\mathrm{N}=182\end{array}$} & \multicolumn{2}{|c|}{$\begin{array}{l}\text { Male } \\
\mathrm{N}=61\end{array}$} \\
\hline & & $\mathrm{N}$ & $\%$ & $\mathrm{~N}$ & $\%$ \\
\hline Avoidance & I prefer being silent & 6 & 3.3 & 7 & 11.5 \\
\hline \multirow{2}{*}{ Strategy } & I go away from there & 5 & 2.7 & 4 & 6.6 \\
\hline & I forget over time & 2 & 1.1 & 1 & 1.6 \\
\hline Total & & 13 & 7.1 & 12 & 19.7 \\
\hline Destructive & I threaten him/her & 4 & 2.2 & 6 & 9.8 \\
\hline \multirow{3}{*}{ Strategy } & I report him/her to the lecturer & 21 & 11.5 & 2 & 3.3 \\
\hline & I stop being friends with him/her & 3 & 1.6 & 5 & 8.2 \\
\hline & & 28 & 15.4 & 13 & 21.3 \\
\hline \multicolumn{6}{|l|}{ Total } \\
\hline \multirow{3}{*}{$\begin{array}{l}\text { Conditional } \\
\text { Strategy }\end{array}$} & I try to solve it by talking first. If I & 35 & 19.2 & 7 & 11.5 \\
\hline & $\begin{array}{l}\text { can't get the result, I threaten } \\
\text { him/her }\end{array}$ & & & & \\
\hline & $\begin{array}{l}\text { First, I warn him/her. If he/she } \\
\text { does it again, I report him/her to } \\
\text { the lecturer }\end{array}$ & 32 & 17.6 & 9 & 14.8 \\
\hline Total & & 67 & 36.8 & 16 & 26.2 \\
\hline \multirow[t]{2}{*}{$\begin{array}{l}\text { Cooperative } \\
\text { strategy }\end{array}$} & $\begin{array}{l}\text { I ask him/her why s/he didn't do } \\
\text { the group work, then invite } \\
\text { him/her to work in groups }\end{array}$ & 39 & 21.4 & 11 & 18.3 \\
\hline & & 35 & 19.2 & 9 & 14.8 \\
\hline
\end{tabular}




\begin{tabular}{llcccc}
\hline & & \multicolumn{2}{c}{$\begin{array}{c}\text { Female } \\
\mathbf{N = 1 8 2}\end{array}$} & \multicolumn{2}{c}{$\begin{array}{c}\text { Male } \\
\mathbf{N = 6 1}\end{array}$} \\
\hline Strategies & Tactics & $\mathrm{N}$ & $\%$ & $\mathrm{~N}$ & $\%$ \\
\hline & $\begin{array}{l}\text { I tell him/her that what he/she } \\
\text { does is wrong then invite him/her } \\
\text { to work in groups }\end{array}$ & & & & \\
Total & & 74 & 40.7 & 20 & 32.8 \\
\hline Total & 182 & 100 & 61 & 100 \\
\hline
\end{tabular}

Based on Table 3, it was found that conflict resolution strategies and tactics in resolving conflicts encountered when working on their assignments implemented by female students was the cooperative strategy with a total of 74 students $(40.7 \%)$. Male students also preferred the cooperative strategy with a total of 20 students (32.8\%). It can be concluded that female students and male students were included in the good category in resolving conflicts when completing tasks in groups. The results of the questionnaire for the second conflict are as follows:

Table 4. PGSD students' conflict resolution strategies and tactics in solving bullying problems

\begin{tabular}{|c|c|c|c|c|c|}
\hline \multirow[b]{2}{*}{ Strategies } & \multirow[b]{2}{*}{ Tactics } & \multicolumn{2}{|c|}{$\begin{array}{c}\text { Female } \\
\mathrm{N}=182\end{array}$} & \multicolumn{2}{|c|}{$\begin{array}{l}\text { Male } \\
\mathrm{N}=61\end{array}$} \\
\hline & & $\mathrm{N}$ & $\%$ & $\mathrm{~N}$ & $\%$ \\
\hline Avoidance & I prefer being silent & 9 & 5 & 2 & 3.3 \\
\hline \multirow[t]{2}{*}{ Strategy } & I go away from there & 8 & 4.4 & 3 & 5 \\
\hline & I forget over time & 2 & 1.1 & 1 & 1.6 \\
\hline Total & & 19 & 10.4 & 6 & 9.8 \\
\hline Destructive & I threaten him/her & 8 & 4.4 & 13 & 21.3 \\
\hline \multirow{2}{*}{ Strategy } & I do the same to him/her & 34 & 18.7 & 21 & 34.4 \\
\hline & I stop being friends with him/her & 5 & 2.8 & 2 & 3.3 \\
\hline Total & & 47 & 25.8 & 36 & 59 \\
\hline $\begin{array}{l}\text { Conditional } \\
\text { Strategy }\end{array}$ & $\begin{array}{l}\text { First, I try to solve it by talking. If I } \\
\text { can't get the result, I threaten } \\
\text { him/her }\end{array}$ & 34 & 18.7 & 4 & 6.6 \\
\hline \multirow{2}{*}{ Total } & $\begin{array}{l}\text { First, I warn him/her. If he/she does } \\
\text { it again, I do the same to him/her }\end{array}$ & 21 & 11.5 & 3 & 5 \\
\hline & & 55 & 30.2 & 7 & 11.5 \\
\hline \multirow[t]{2}{*}{$\begin{array}{l}\text { Cooperative } \\
\text { strategy }\end{array}$} & $\begin{array}{l}\text { I ask him/her why he/she bullies me, } \\
\text { then tell him/her to apologize }\end{array}$ & 37 & 20.3 & 9 & 14.8 \\
\hline & $\begin{array}{l}\text { I tell him/her that what s/he does is } \\
\text { wrong, then tell him/her to } \\
\text { apologize }\end{array}$ & 24 & 13.2 & 3 & 5 \\
\hline Total & & 61 & 33.5 & 12 & 19.7 \\
\hline Total & & 182 & 100 & 61 & 100 \\
\hline
\end{tabular}

Table 4 presents that the most chosen strategy to resolve the bullying conflict by female students was the cooperative strategy with a total of 61 (33.5\%). Meanwhile, male students chose the destructive strategy with a number of 36 students (59\%). It can be concluded that 
Galih Dani Septiyan Rahayu, Bunyamin Maftuh \& Elly Malihah, An Investigation of Conflict Resolution...

female students are better than male students in resolving conflicts regarding bullying. And for the results of the questionnaire for the third conflict are as follows:

Table 5. PGSD students' conflict resolution strategies and tactics in resolving discriminatory problems

\begin{tabular}{|c|c|c|c|c|c|}
\hline \multirow[b]{2}{*}{ Strategies } & \multirow[b]{2}{*}{ Tactics } & \multicolumn{2}{|c|}{$\begin{array}{c}\text { Female } \\
N=182\end{array}$} & \multicolumn{2}{|c|}{$\begin{array}{l}\text { Male } \\
\mathrm{N}=61\end{array}$} \\
\hline & & $\mathrm{N}$ & $\%$ & $\mathrm{~N}$ & $\%$ \\
\hline Avoidance & I prefer being silent & 3 & 1.7 & 2 & 3.3 \\
\hline \multirow[t]{2}{*}{ Strategy } & I go away from there & 10 & 5.5 & 5 & 8.2 \\
\hline & I forget over time & 2 & 1.1 & 4 & 6.6 \\
\hline Total & & 15 & 8.2 & 11 & 18 \\
\hline Destructive & I threaten him/her & 1 & 0.6 & 11 & 18 \\
\hline \multirow{2}{*}{ Strategy } & I do the same to him/her & 8 & 4.4 & 3 & 5 \\
\hline & I stop being friends with him/her & 13 & 7.1 & 2 & 3.3 \\
\hline Total & & 22 & 12.1 & 16 & 26.2 \\
\hline \multirow[t]{2}{*}{$\begin{array}{l}\text { Conditional } \\
\text { Strategy }\end{array}$} & $\begin{array}{l}\text { First, I try to solve it by talking. If I } \\
\text { can't get the result, I report him/her } \\
\text { to the lecturer }\end{array}$ & 31 & 13 & 9 & 14.8 \\
\hline & $\begin{array}{l}\text { First, I warn him/her. If he/she does } \\
\text { it again, I stop being friends with } \\
\text { him/her }\end{array}$ & 36 & 19.8 & 7 & 11.5 \\
\hline Total & & 67 & 36.8 & 16 & 26.2 \\
\hline \multirow[t]{2}{*}{$\begin{array}{l}\text { Cooperative } \\
\text { strategy }\end{array}$} & $\begin{array}{l}\text { ask him why he/she is } \\
\text { discriminatory, then tell him/her to } \\
\text { apologize }\end{array}$ & 36 & 19.8 & 12 & 19.7 \\
\hline & $\begin{array}{l}\text { I tell him/her that what he/she does } \\
\text { is wrong, then tell him/her to } \\
\text { apologize }\end{array}$ & 42 & 23.1 & 6 & 9.8 \\
\hline Total & & 78 & 42.9 & 18 & 29.5 \\
\hline Total & & 182 & 100 & 61 & 100 \\
\hline
\end{tabular}

Table 5 above shows that the most chosen strategy to resolve the discriminatory conflict by female students was the cooperative strategy with a total of 78 students (42.9\%). Male students also preferred the cooperative strategy with 18 students (29.5\%). It can be concluded that female students and male students are included in the good category in resolving discriminatory conflicts. And for the results of the questionnaire for the fourth conflict are as follows:

Table 6. PGSD students' conflict resolution strategies and tactics in resolving taking things without permission problem

\begin{tabular}{llcccc}
\hline & & \multicolumn{2}{c}{$\begin{array}{c}\text { Female } \\
\mathbf{N = 1 8 2}\end{array}$} & \multicolumn{2}{c}{$\begin{array}{c}\text { Male } \\
\mathbf{N}=6 \mathbf{6 1}\end{array}$} \\
\hline Strategies & Tactics & $\mathrm{N}$ & $\%$ & $\mathrm{~N}$ & $\%$ \\
\hline Avoidance & I prefer being silent & 7 & 3.8 & 7 & 11.5 \\
Strategy & I go away from there & 9 & 5 & 3 & 4.9 \\
& I forget over time & 1 & 0.5 & 3 & 4.9 \\
Total & & 17 & 9.3 & 13 & 21.3 \\
\hline Destructive & I threaten him/her & 2 & 1.1 & 6 & 9.8 \\
\hline
\end{tabular}




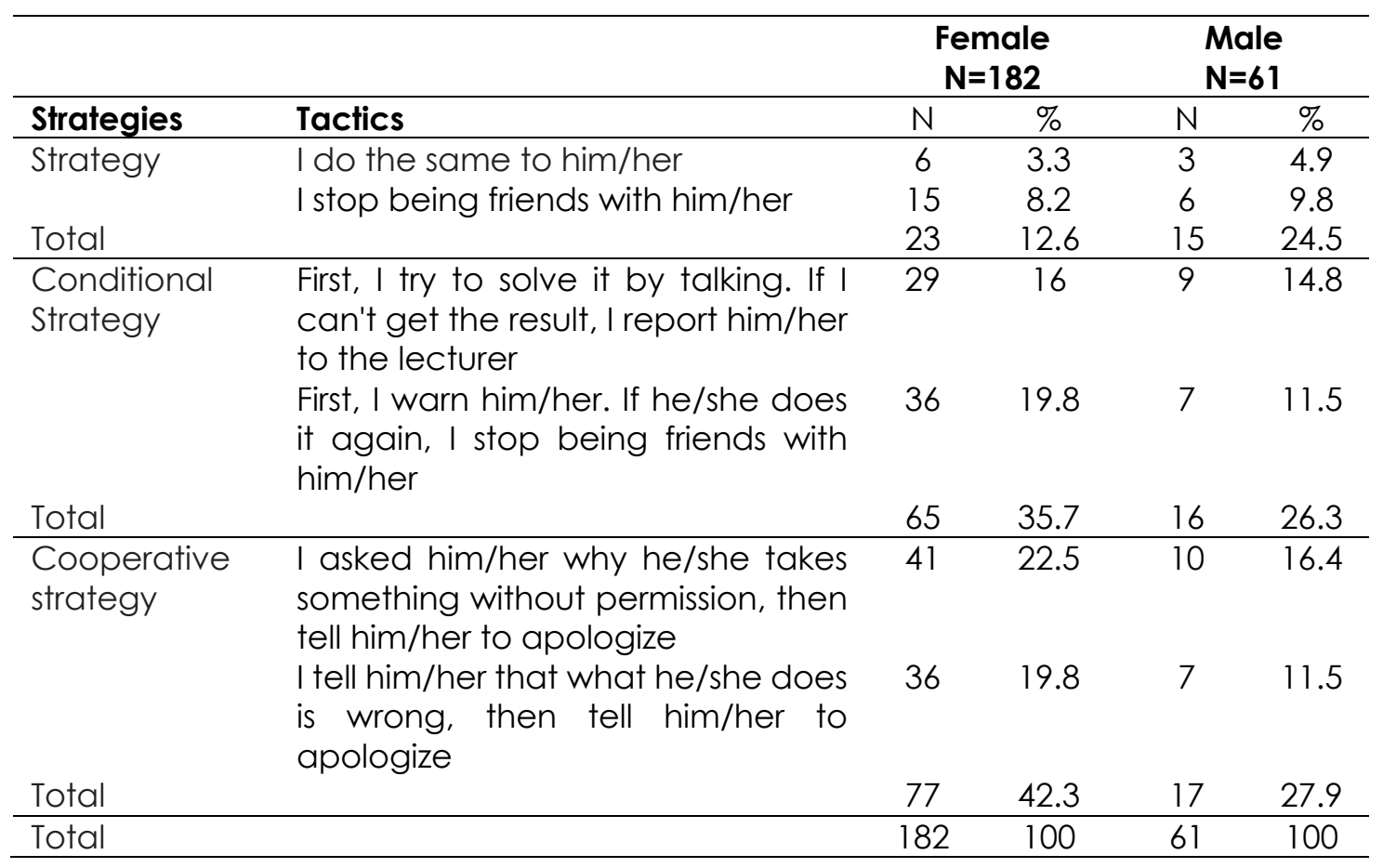

Table 6 presents that the most chosen strategy to resolve taking things without permission conflict by female students was the cooperative strategy with a total of 77 students $(2.3 \%)$. Male students also preferred the cooperative strategy with a total of 17 students (27.9\%). It can be concluded that female students and male students are included in the good category in resolving conflicts of taking other people's things/works without permission.

\section{DISCUSSION}

This study aims at identifying the experiences of PGSD students during online learning, specifically regarding the conflicts experienced by them. The online learning that is the focus of this study is the learning of elementary school social studies courses taught to $4^{\text {th }}$ semester students of a private university in West Java, totaling 243 students that consist of 182 female students and 61 male students.

Following data processing and of data obtained from interviews, it shows that the conflict experienced by students is a conflict encountered when completing tasks in groups. The conflict they experienced was that in every group there were always students who did not participate in the conflict resolution process for various reasons such as network constraints, difficulty in obtaining references, difficulty in communicating, inadequate understanding of the tasks that must be completed in groups, and low motivation from students. In addition to network constraints, it can be concluded that the communication pattern in diversity has not been maximized as a trigger for the conflict (Böhm et al., 2021; Shimanovskay \& Sarychev, 2021). 
Galih Dani Septiyan Rahayu, Bunyamin Maftuh \& Elly Malihah, An Investigation of Conflict Resolution...

Following an analysis on data obtained from the questionnaires, it shows that female and male students are included in the good category in resolving conflicts when completing tasks in groups, namely by choosing a cooperative strategy with the following tactics: asking him/her why he/she didn't do the group work, then inviting him/her to work in the groups and telling him/her that what he/she did was wrong and then inviting him/her to work in the group. The selection of these strategies and tactics, according to the students, is based on several things, namely the students' awareness that students who do not participate in working on assignments may be based on logical reasons so it is necessary to confirm to the students concerned and the awareness of students that cooperative strategy is a good strategy (Asha \& Hawi, 2016; Bakken \& Buhaug, 2021; Mishra, 2021).

The second conflict experienced by the students was bullying. Following an analysis on data obtained from the questionnaires, as presented in the results section, the most chosen strategy by female students was the cooperative strategy. Based on this, female students are calmer in dealing with conflicts regarding bullying. Female students have a more stable emotional level than male students (Supriyadi et al., 2019; Vogler et al., 2019).

Meanwhile, male students prefer the destructive strategy with tactics of doing the same thing when there are students who are bullying them, they bully back. This is in line with the nature of male students whose emotions are less stable in dealing with a problem (Kadarisma et al., 2019; Skordoulis et al., 2020; Yavuzer, 2012). This is certainly not a good strategy because with a destructive strategy, the conflict will not be resolved (Ay et al., 2019; Türk, 2017).

The third conflict experienced by students was the discriminatory attitude during online learning. This discriminatory attitude occurs when the group is divided, where there are some students who are not invited to join the group by some other students for various reasons, one of which is that students want to work in groups only with close friends and students do not want to group with students who have differences (Bayraktar \& Yilmaz, 2016; Karacabey et al., 2019; Karataş, 2011). However, in solving these discriminatory problems, the strategies and tactics that were most chosen by female and male students were good, namely the cooperative strategy.

The fourth conflict experienced by students during online learning the recognition of work results and taking things without permission. The most chosen strategy by female and male students is the cooperative strategy with the following tactics: asking him/her why he/she took something without permission, then telling him/her to apologize, and telling him/her that what he/she did was wrong, then telling him/her to apologize. The students, both female and male, confirmed that they realized that claiming or taking other people's things/works is a negative thing that triggers a conflict. The choice of this strategy is influenced by students' experiences during learning that it is better to resolve conflicts though good communication with individuals 
who are the target of conflict (Ciuladiene \& Kairiene, 2017; Pieng \& Okamoto, 2020; Scorzelli, 2012).

Based on the results and findings discussed above, the role of educators in solving problems or conflicts in the classroom is necessary, particularly in directing students to understand conflicts and resolve conflicts by integrating conflict resolution education in the learning process (Iqbal et al., 2017). In addition, the selection of a cooperative strategy in conflict resolution is also influenced by the students' prior learning experiences in the previous semesters when they studied in groups. Thus, it can be concluded that group learning can have a positive impact in choosing strategies and tactics in resolving conflicts or problems (Crawford \& Bodine, 1996; Doe \& Chinda, 2015; Kreidler, 1997).

\section{CONCLUSION}

Based on the results and findings of the study, it was found that during online learning students experience various conflicts, namely conflicts in completing group assignments, bullying between students, students' discriminatory attitudes towards one another, and recognition of creativity or work of other people without permission and taking other people's things without permission. In this study, it can be concluded that female students choose a cooperative strategy in resolving conflicts, while male students did not resolve the four conflicts with a cooperative strategy, particularly in conflicts caused by bullying, they chose destructive strategies instead. In addition, it can also be concluded that the group learning experience and the role of educators also have an influence in the selection of strategies in resolving conflicts.

Based on these conclusions, recommendations for other researchers who will study conflict resolution are to conduct studies with a broader subject and develop the results of this study so that it can benefit students and lecturers, especially in conflict resolution studies. Recommendations for related parties are that the results and findings in this study are expected to create learning that is in accordance with student strategies in resolving conflicts so that a peaceful class can be realized.

\section{ACKNOWLEDGMENTS}

Thank you to the IKIP Siliwangi Elementary School Teacher Education Study Program that has given permission for the implementation of this study so that it can run in an orderly process and as expected.

\section{REFERENCES}

Akan, Y. (2020). An analysis on the effect of violence reduction psychoeducation program on communication, conflict resolution and empathy skill levels of adolescent students. 
Galih Dani Septiyan Rahayu, Bunyamin Maftuh \& Elly Malihah, An Investigation of Conflict Resolution...

European Journal of Education Studies, 7(7), 225-242. https://doi.org/10.46827/ejes.v7i7.3167

Asha, D. I. K., \& Hawi, A. M. A. (2016). The Impact of cooperative learning on developing the sixth grade students decision-making skill and academic achievement. Journal of $\begin{array}{lll}\text { Education } \quad \text { and } & \text { 60-67. }\end{array}$ https://iiste.org/Journals/index.php/JEP/article/view/29824

Ay, ş. Ç., Keskin, H. K., \& Akıllı, M. (2019). Examining the Effects of Negotiation and Peer Mediation on Students' Conflict Resolution and Problem-Solving Skills. International Journal of Instruction, 12 (3), 717-730. https://doi.org/10.29333/iji.2019.12343a

Ayas, T., Deniz, M., Kağan, M., \& Kenç, M. F. (2010). An investigation of conflict resolution strategies of adolescents. Procedia - Social and Behavioral Sciences, 2(2), 3545-3551. https://doi.org/10.1016/j.sbspro.2010.03.549

Bakken, I. V., \& Buhaug, H. (2021). Civil War and Female Empowerment. Journal of Conflict Resolution, 65(5), 982-1009. https://doi.org/10.1177/0022002720983409

Bayraktar, H. V., \& Yilmaz, K. Ö. (2016). Investigation of primary school teachers' conflict resolution skills in terms of different variables. Journal of Education and Training Studies, 4(9), 222-231. https://doi.org/10.11114/jets.v4i9.1741

Böhm, R., Fleiß, J., \& Rybnicek, R. (2021). On the Stability of Social Preferences in Inter-Group Conflict: A Lab-in-the-Field Panel Study. Journal of Conflict Resolution, 65(6), 1215-1248. https://doi.org/10.1177/0022002721994080

Ciuladiene, G., \& Kairiene, B. (2017). The Resolution of Conflict between Teacher and Student: Studentsí Narratives. Journal of Teacher Education for Sustainability, 19(2), 107-120. https://doi.org/10.1515/jtes-2017-0017

Crawford, D., \& Bodine, R. (1996). A guide to implementing programs in schools, youth-serving organizations, and community and juvenile justice settings. Department of Justice.

Doe, L., \& Chinda, N. (2015). Principals' and teachers' use of conflict management strategies on secondary students' conflict resolution in rivers state- Nigeria. Journal of Education and Practice, 6(13), 148-153. https://eric.ed.gov/?id=EJ1080516

Gall, M. D., Gall, J. P., \& Borg, W. R. (2014). Applying educational research: How to read, do, and use research to solve problems of practice (Sixth). Pearson Education.

Gibbons, K. (2010). Circle justice: A creative arts approach to conflict resolution in the classroom. Art Therapy, 27(2), 84-89. https://doi.org/10.1080/07421656.2010.10129716

Guo, S., \& Yang, Y. (2012). Project-based learning: An effective approach to link teacher professional development and students learning. Journal of Educational Technology Development and Exchange, 5(2), 42-56. https://doi.org/10.18785/jetde.0502.04

Iqbal, K., Khalil, U., \& Khan, A. (2017). Perceptions of secondary school teachers regarding the role of education in social conflict resolution. Bulletin of Education and Research, 39(3), 157-170. https://doi.org/eric.ed.gov/fulltext/EJ1210308 
Kadarisma, G., Nurjaman, A., Sari, I. P., \& Amelia, R. (2019). Gender and mathematical reasoning ability. Journal of Physics: Conference Series, 1157, 042109. https://doi.org/10.1088/1742-6596/1157/4/042109

Karacabey, M. F., Ozdere, M., \& Bozkus, K. (2019). The Attitudes of Teachers towards Multicultural Education. European Journal of Educational Research, 8(1). https://doi.org/10.12973/eu-jer.8.1.383

Karataş, Z. (2011). Investigating the effects of group practice performed using psychodrama techniques on adolescents' conflict resolution skills. Educational Sciences: Theory and Practice, 11 (2), 609-614. https://eric.ed.gov/?id=EJ927368

Kreidler, W. J. (1997). Conflict resolution in the middle school. Educators for social responsibility. Mishra, L. (2021). Peace education in secondary schools of Mizoram. Conflict Resolution Quarterly, 38(4), 323-333. https://doi.org/10.1002/crq.21311

Pieng, P., \& Okamoto, Y. (2020). Examining preschool children's intention understanding and their conflict resolution strategies. Early Childhood Education Journal, 48(5), 597-606. https://doi.org/10.1007/s10643-020-01020-0

Rahayu, G. D. S., Bernard, M., Mulyono, D., \& Rabbani, S. (2020). VBA media development for microsoft excel against students' mathematical problem solving. Journal of Physics: Conference Series, 1657, 012079. https://doi.org/10.1088/1742-6596/1657/1/012079

Rahayu, G. D. S., \& Fauzi, M. R. (2020). The effect of the project-based learning model on students' resilience during the pandemic covid-19. JPI (Jurnal Pendidikan Indonesia), 9(4), 711. https://doi.org/10.23887/jpi-undiksha.v9i4.27390

Scorzelli, J. F. (2012). University Students' Perceptions of Conflict Resolution. Journal of International Students, 2(1), 87-92. https://doi.org/10.32674/jis.v2i1.537

Shanka, E. B., \& Thuo, M. (2017). Conflict Management and Resolution Strategies between Teachers and School Leaders in Primary Schools of Wolaita Zone, Ethiopia. Journal of Education and Practice, 8(4), 63-74.

Shimanovskay, Y. a V., \& Sarychev, A. S. (2021). Improvement of the efficiency of adolescents' interpersonal interaction in conflict resolution. Propósitos y Representaciones, 9(SPE2). https://doi.org/10.20511/pyr2021.v9nSPE2.989

Skordoulis, M., Koukounaras Liagkis, M., Sidiropoulos, G., \& Drosos, D. (2020). Emotional intelligence and workplace conflict resolution: The case of secondary education teachers in Greece. International Journal of Research in Education and Science, 6(4), 521. https://doi.org/10.46328/ijres.v6i4.1224

Supriyadi, T., Julia, j, \& Firdaus, E. (2019). The problems of gender equality: A reconstruction of Islamic doctrine. Journal of Social Studies Education Research, 10(2), 91-110. https://jsser.org/index.php/jsser/article/view/698

Tuimur, H. N., \& Chemwei, B. (2015). Availability and use of instructional materials in the teaching of conflict and conflict resolution in primary schools in Nandi North District, Kenya. 
Galih Dani Septiyan Rahayu, Bunyamin Maftuh \& Elly Malihah, An Investigation of Conflict Resolution...

International Journal of Education and Practice, 3(6), 224-234. https://doi.org/10.18488/journal.61/2015.3.6./61.6.224.234

Türk, F. (2017). Evaluation of the effects of conflict resolution, peace education and peer mediation: A meta-analysis study. International Education Studies, 11(1), 25. https://doi.org/10.5539/ies.v1 1n1p25

Vogler, K. E., Pate, S. S.-, \& Allan, A. (2019). Relationship of instructional time configuration, gender and race on seventh grade social studies performance. Journal of Social Studies Education Research, 10(4), 1-25. https://jsser.org/index.php/jsser/issue/view/16 Yavuzer, Y. (2012). Effect of creative drama-based group guidance on male- adolescent conflict resolution skills. 47(1), 113-130. https://eric.ed.gov/?id=EJ1057369 